\title{
MAY 1932
}

\section{Gov. DOCS}

\section{UNIVERSITY OF ILLINOIS}

\section{Agricultural Experiment Station}

\author{
URBANA，ILLINOIS, APRIL，1915
}

CIRCULAR No. 179

\section{FOUR APHIDS INJURIOUS TO THE APPLE}

\author{
By B. S. Pickett
}

Assistant Chief in Pomology

Aphids infesting the apple buds appeared in serious numbers during the present season (I9I5) in the University orchards, when the buds began to swell. They were also observed in neighboring orchards and in the experimental orchards of the Department at Olney and Neoga. In rgr4, apple aphids caused serious damage in certain counties in Illinois, and some damage was reported from many sections of the state. With a view to finding the extent of the present season's infestation, the writer telegraphed to six orchardists in representative parts of the state for information as to the occurrence of the insects. The replies were as follows:

From Johnson county.-Aphis worse than ever before. Something must be done quickly or crop is ruined.

From Marion county.-Aphis situation much more serious this morning (April I0).

From Union county.-Find some aphis but not in alarming numbers.

From Washington county.-Do not find any aphis.

From Jersey county.-Green aphis very bad on almost all orchards.

From Tazewell and McLean counties.-The aphids are very bad at Lilly. At Normal there are some aphids on some trees.

The replies indicate a serious infestation more or less widely spread over the state, and the Department of Horticulture is therefore preparing this brief circular in order to provide information regarding the insects and to suggest measures for their control.

\section{Character of INJURI}

The aphids attack the opening buds, the young fruits, the growing shoots, and the leaves, sucking the plant juices from the succulent parts 
by means of long, very slender, tube-like beaks which they thrust thru the skins of the affected organs into the soft tissues beneath. They weaken the blossom buds by removing the sap; they dwarf and deform the apples so that varieties of ordinary size frequently fail to grow larger than small crab apples, and the fruits have a puckered appearance about the calyx end; they suck the juice from the growing shoots, dwarfing them; and they cause the leaves to curl, and if the insects are present in large numbers, to dry up and fall.off. They are more injurious to the growth of young trees than of old trees. In old trees their chief injuries are on the fruit.

\section{Description of the Aphids}

Four kinds of aphids attack the apple, the Apple Aphis (Aphis pomi DeG.), the Rosy Apple Aphis (Aphis sorbi Kah1.), the European Grain Aphis (Siphocoryne avenac Fab.), and the Clover Aphis (Aphis bakeri Cowen). All kinds are small, soft-bodied, sucking insects reproducing themselves with great rapidity in dry, warm weather. Cold, heavy rains are detrimental to the propagation and development of the insects. The various species differ, however, in their appearance and habits in some important respects.

The Apple Aphis eggs are deposited in the fall on the new shoots and at the base of the bud scales. The eggs are small shining black objects and are often to be found in great numbers. The eggs hatch about the time the buds begin to open, and the aphids may be found infesting the young shoots, expanding leaves, and flower buds. The adults are one-twelfth of an inch long, and bright green in color. This species is particularly partial to the young shoots and tender terminal leaves, but it also deforms and stunts the fruit when present in large numbers during and immediately following the blooming period. The Apple Aphis lives on the apple trees thruout the year.

The Rosy Apple Aphis eggs are deposited in the same manner as those of the Apple Aphis and hatch at the same time in the spring. The adults are slightly larger than those of the Apple Aphis, onetenth of an inch long, and are variable in color, usually rosy, but sometimes gray, purplish, or black. This species is particularly partial to the fruit spurs and destructive to young fruits, tho it also attacks the young shoots and causes the leaves to curl as does the Apple Aphis. Unlike the Apple Aphis, this species, after producing three generations on the apple, migrates to some unknown food plant, where it passes the summer, returning to the apple trees in the fall.

The European Grain Aphis lays its eggs on the apple in the fall and produces two generations on the apple in the spring, after which it migrates to grass and grain crops for the summer, returning to the apple in the fall. The adults are smaller than the previous species and green in color. It infests the flower buds and blossoms to an even greater extent than the Apple Aphis or the Rosy Apple Aphis, but, 
owing to its earlier migration, it is less injurious to the leaves and young shoots.

The Clover Aphis lays its eggs in the fall on the shoots of the apple. The eggs hatch a week or more before the Apple Aphis. Most of the aphids migrate to clover or alfalfa in June, tho a few appear to remain on the apple thruout the season. The adults are light yellow or pink in color.

All the species described occur in Illinois, and more than one of them may be found the same season in the same orchard. In fact it is quite possible that all four species are sometimes present in the same orchard. Information as to the relative seriousness of the different species is, unfortunately, incomplete; orchardists are advised to observe carefully the habits and appearance of these insects as they have opportunity in their orchards, in order to identify the species and to determine whether or not the particular species present is causing sufficient injury to call for remedial measures. During the present season orchardists should make an immediate examination of their trees and if aphids are found in large numbers, should take immediate steps to combat them. Growers whose orchards suffered in IgI4 should be especially prepared to fight these pests this spring.

\section{Remedial Measures}

The species of aphids above described are easily killed in the adult stage by certain contact sprays. Winter applications of lime sulfur cannot be depended on to destroy the eggs. Poison sprays such as arsenate of lead are not eaten by this type of insect, and consequently are ineffective remedies for aphids. Kerosene emulsion is effective but is uncertain in its effect on the foliage of the trees. The best available sprays are the tobacco decoctions, of which the one most widely in use is "Black Leaf 40," a proprietary tobacco extract, made by the Kentucky Tobacco Products Company, Louisville, Kentucky. This material is used at the rate of one gallon in one thousand gallons of spray. It may be combined with lime sulfur, lime sulfur arsenate of lead, Bordeaux, or Bordeaux arsenate of lead, not with arsenate of lead alone.

The ideal time to spray for these aphids is just as soon as all or nearly all the eggs appear to have hatched. Observations made in the University orchards this season indicate that all the eggs hatched before the blossom buds began to separate. After the leaves expand somewhat and the blossom buds separate, the aphids are provided with more hiding places and are more difficult to hit with the spray. Unfortunately, spraying at this time would require an extra application in addition to the cluster bud spray (made for scab, curculio, bud moth, spring canker worms, etc.), and would thus add seriously to the cost of the season's operations. Spraying for aphids at the time of the cluster bud spray is, however, highly effective, and in general it is

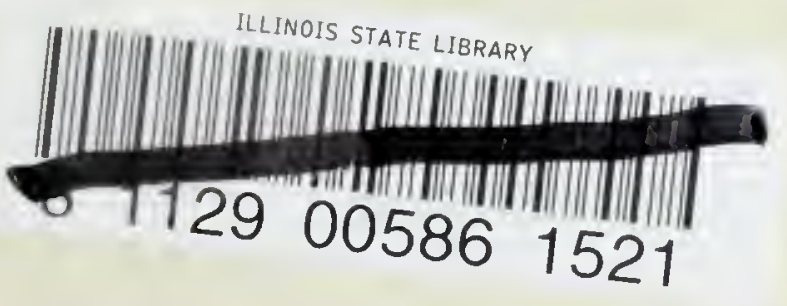


advised that this method be followed. If, however, previous experience has shown serious losses from aphids, or if they are present in extremely large numbers, the extra application may be well worth while.

Fruit growers will confer a favor on the Department of Horticulture if they will write us the results of their observations on the behavior of the aphids during the present season. The points on which information is particularly desired are the time of appearance and extent of the infestation, the color of the adults, the duration of the attack, the disappearance and reappearance of the aphids, if these occur, and the success or failure of any remedial measures tried. Such information will be very helpful in determining the extent of the need for treatments and the character of the treatments themselves. 